\title{
Spanish learning strategies of some good language learners
}

\author{
Manuel Morales \\ Bethel College, Mishawaka, Indiana \\ Daniel J. SMith \\ Department of Languages, Clemson University \\ South Carolina
}

Received: 21 April 2007 / Accepted: 13 September 2007

ISSN: $1697-7467$

\begin{abstract}
Students of Spanish share their own visual and verbal strategies for quickly grasping grammatical complexities which often baffle the average student of Spanish. The same students also demonstrate high levels of motivation to learn and acquire Spanish and sometimes other languages in addition to Spanish. This study is a description of what several highly motivated students do to learn and acquire Spanish. These students attain high levels of proficiency on the ACTFL proficiency scale as compared to average students of Spanish.
\end{abstract}

Key words: mental images, visualization, mnemonics, memorization, grammar, motivation

RESUMEN: Algunos estudiantes de español intercambian sus propias estrategias visuales y verbales para poder aprender rápidamente las complejidades gramaticales que frecuentemente desconciertan al estudiante medio de español. Los mismos estudiantes demuestran también altos niveles de motivación para aprender y adquirir español y a veces otras lenguas además del español. Este estudio es una descripción de lo que hacen varios estudiantes muy motivados para aprender y adquirir español. Estos estudiantes consiguen altos niveles de proficiencia en la escala de proficiencia de ACTFL en comparación con los estudiantes medios de español.

Palabras clave: imágenes mentales, visualización, asociaciones para memorizar, gramática, motivación

\section{INTRODUCTION}

This study examines the learning strategies of twenty motivated students of Spanish as a second language. These students have demonstrated a surprising progress relevant to average rates of progress, implying that the learning strategies they used are very good ones to follow. The study focuses on how students successfully negotiated difficulties in morphosyntax using mental images which combine visual and verbal representations. The twenty students observed in this study include adult university students and home-schooled children.

The study here illustrates the conclusions drawn from the second language acquisition research of Anderson (1980), O'Malley and Chamot (1990), and Oxford (1990). They point 
out the effectiveness of consciously associating grammatical information with mental images and the consequent transfer of learned grammatical information to the subconscious or automatic storing of linguistic information as the practical ability to use a second language.

\section{LANGUAGE LEARNing STRATEgies AND MENTAL IMAGES}

According to Oxford (1990), memory strategies have four aspects (see Figure 1): Creating mental associations, Applying visual images and sounds, Reviewing well, and Employing/ using actions. The first letter of the label for each aspect is used to form the acronym CARE.

Figure 1. Diagram of memory strategies (Oxford, 1990: 39).

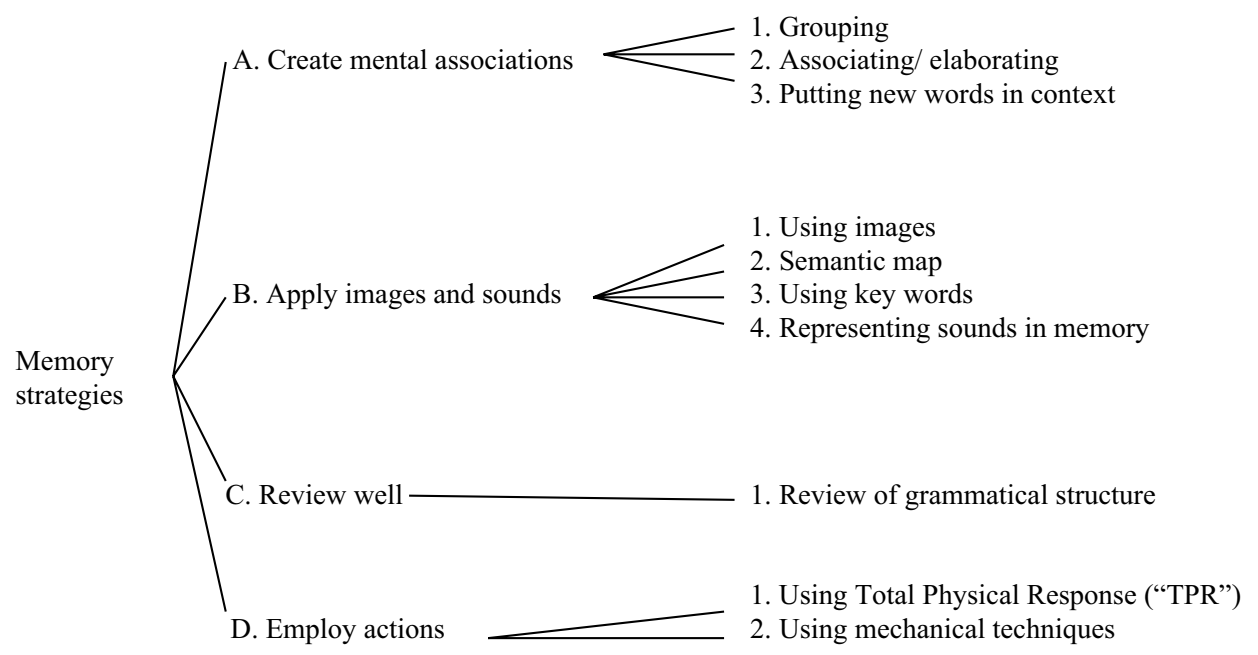

For Oxford, the process of relating the verbal with mental images has four advantages. First: the mental storage for visual information exceeds the verbal. Second: the most efficient transmission of information to long-term memory is through mental images. Third: mental images are the most efficient help in the retrieval of verbal material. Fourth: the majority of learners prefer visual learning.

The connections between what is learned during second language classes and mental images are possible due to students' using their conscious knowledge. In other words, the learner should be conscious of his/her learning when he/she produces these connections, that is to say that learning is achieved explicitly. Oxford indicates that in the strategy of reviewing grammatical structure (see Figure 1), the student moves his/her information from a factual level to a skill level, thus moving the information from the conscious level to the automatic. 
Manuel Morales, Daniel J. Smith Spanish learning strategies of some good language learners

Anderson (1980: 224) connects learning and acquisition:

When we learn a foreign language in a classroom situation, we are aware of the rules of the language, especially just after a lesson that spells them out. One might argue that our knowledge of the language at that time is declarative. We speak the learned language by using general rule-following procedures applied to the rules we have learned, rather than speaking directly, as we do in our native language. Not surprisingly, applying this knowledge is a much slower and more painful process than applying the procedurally encoded knowledge of our own language. Eventually, if we are lucky, we can come to know a foreign language as well as we know our native language. At that point, we often forget the rules of the foreign language. It is as if the class-taught declarative knowledge had been transformed into a procedural form.

O'Malley and Chamot (1990) point out that learning strategies are complex procedures and therefore are represented as declarative knowledge, which can be acquired in a cognitive or associative way. The strategies can be declarative and conscious at the beginning and then become transformed into automatic procedures subconsciously.

The following students were observed as illustrations of the effectiveness of the research conclusions of Anderson, O'Malley and Chamot, and Oxford. We have divided the university and home-schooled students of the study into six groups, groups A, B, C, D, E, and F. The students were divided into groups according to the similarity of instruction and language exposure within each group. In other words, students from the same class were grouped together and students from the same home-schooled family were grouped together.

\section{Group a: UNIVERSity STUDENTS IN THE CLASSROOM}

The first group of students, group A, is from a second semester Spanish honors class at Temple University in Philadelphia, Pennsylvania. They were asked to keep a diary of mistakes and to record what memory strategies they used in order to master their areas of difficulty. Students in each group are referenced by numbers. For example, since there are 8 students in group A, each student is referenced as follows: A1, A2, A3, A4, A5, A6, A7, and A8.

Student A1 wrote in his diary about the "shoe verbs" (boot, shoe, sandal). The mental image of the boot represents Spanish present tense stem-changing verbs such as pensar and dormir which stem-change in each person except first and second persons plural. The image of the shoe represents present tense stem-changing verbs such as tener which only stemchange in the second and third persons singular and third person plural. The image of the sandal represents those Spanish verbs in the preterit tense which only stem change in the third person singular and plural. Figures 2-4 [change the figures 1-3 to 2-4] illustrate the three types of shoe verbs. 
The shoe verbs in Spanish

Figure 2: The shoe verbs.

Present tense of pensar

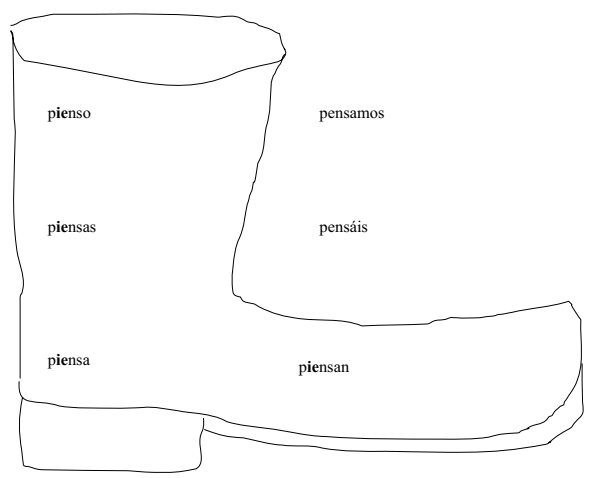

Figure 3: The shoe verbs.

Present tense of tener

tengo tenemos

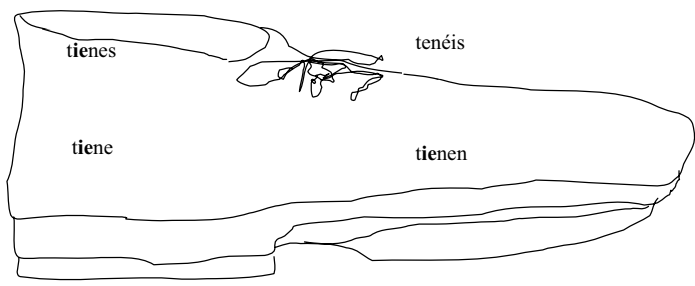

Figure 4: The sandal verbs.

Preterit tense of dormir

dormí dormimos

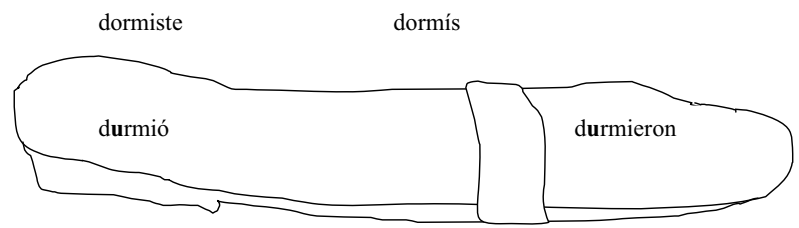


Student A1 wrote that seeing pictures of the different shapes of shoes helped him to understand verbs such as the "sandal verbs" (the stem-changing verbs in the third person singular and plural). His problem now was to record which ones corresponded to this category. To resolve this difficulty other students in the class created a short story that connected these verbs with the concept of the "sandal verbs" by using the verbs in this category in the short story.

Student A1 also addressed the problem of when to use the Spanish verbs tocar 'to play (a musical instrument)' and jugar 'to play (a game or sport)', both meaning 'to play' (either games/sports or musical instruments) in English. He noted the mistakes in his compositions and concluded that the reason for his mistakenly using the verb jugar for both games/sports and musical instruments was because he plays many sports but plays no musical instrument. These written and mental notations helped him to remember the difference between the two verbs.

Student A2 wrote in his diary how to remember the Spanish demonstratives, este, estos 'this, these' and ese, esos 'that, those': "this and these have $t$ 's, and that and those do not," meaning that the Spanish este, estos have the [t] sound and ese, esos do not. To remember that the Spanish for television is feminine, he wrote: "Beautiful women appear on television." To study the irregular preterit of the verb hacer, he noted: "Yo hice; él hizo; I made the center and he made the outside zone."

Student A3 had problems with whether to use the prepositions por or para, a very difficult problem for most students of Spanish, since the English prepositions used for por and para frequently do not correspond. The por/para dilemma was in large part resolved when student A3 heard stories and saw pictures that illustrated their uses. He drew some of the uses of the preposition para with a paracaídas ("PARAcaídas" or in English 'parachute') and with an arrow pointing toward the earth. The arrow indicated arriving at the deadline, since para is used for expressing arriving at places and by deadlines. For example, Voy para Madrid 'I'm going to Madrid' and Entrega la tarea para mañana 'Turn in the homework by tomorrow.' For the preposition por, he drew the picture of a man leaving by way of the door since in Spanish 'door' is puerta, and the puer- syllable is much more similar in sound to por than to para. He used the preposition por also to indicate duration of time as in estudié por tres horas 'I studied for three hours'; to visualize and remember this he drew a watch with curved arrows (the opposite of the straight arrow used for the preposition para) signifying a duration of time. Regarding usage of por for time expressions he also made the following note: "temPORal".

Student A4 described in his diary how he remembered that the word "día" is masculine in Spanish; he wrote the following: "day = 3 letters; di $a=3$ letters; boy $=3$ letters; in English boy $=3$ letters; in Spanish día $=3$ letters; therefore día is masculine (día $=3$, boy $=3$ ); whereas girl in English has 4 letters." Another grammatical point was how to correctly use the Spanish tener ganas de 'to feel like doing (something)'; his solution was: "equate 'tener with 'to have' and not 'to feel'( 'to feel like'); when I think of the literal translation which is 'to have desires of' it is much easier to remember." Regarding reflexive verbs, student A4 noted: "reflexive verbs = self, se/ self; so when he/she/ you(formal) is doing something to himself, you use se and not le." He equated reflexive se with self as a memory device.

Student A5 was from Italy and therefore did not have many of the same pronunciation problems that American students have. In his diary, however, we found that he had a problem with the pronunciation of the frequently used Spanish conjunction pero. The student wrote: 
"I pronounce this word in a wrong way. This has to do with the fact that when I say a word I make it sound louder to give myself time to think about what I am going to say next." His pronunciation consisted of stretching out the last syllable to the point of making the other students in class laugh. Further along in his diary we found the solution that helped him to correct his pronunciation of pero: "Since in Italian the word for tree [pear tree] is pronounced the same way as pero 'but' in Spanish, I don't make this mistake so often anymore." Also, he associated the pronunciation of 'pero' with 'perro' without pronouncing the double ' $r$ '.

Student A6 commented in his diary how to memorize the word mantequilla 'butter' with the following story: "I remember my high school Spanish teacher in $11^{\text {th }}$ grade telling me that butter is pronounced like meant to kill ya." The student spoke further of his teacher:" I remember it because he never made a joke; it was nothing but word repetition ..., but he said that and actually laughed; that is why I remember it." His diary also revealed a way to learn the endings of imperfect '-ar' verbs: "Imperfect is used for a repeated action in the past. I remember this because the ending for the '-ar' verbs are '-aba'. This makes me think of someone 'blabbing' on about something - a never ending conversation. Time is never ending; therefore [it] must be imperfect."

Student A7 is very graphic and visual. His diary was filled with colors and diagrams in which he had the habit of highlighting his mistakes with certain colors and using other colors for his solutions. He used bright colors to draw his attention to the correct answers. For example, for the word teléfono he wrote the incorrect definite article. In his diary he highlighted or colored the word teléfono, writing it as "tELéfono", and writing the masculine article el before it, in the same color: "EL tELéfono".

Student A8 made the following entry in his diary about the irregular preterit: "Today in class there was a discussion on how to remember to use only -eron for an ending on verbs which change ... [regular] -ieron [to -eron] in the preterit tense (in the $3^{\text {rd }}$ person), for example: dijeron, condujeron, trajeron. None of them use an ' $i$ ' in the ending. I came up with the idea that in Michael Jordan's team, there is no place for 'I' in his team." Student A8 had made the association with the ' $\mathrm{j}$ ' in Michael Jordan's name and the ' $\mathrm{j}$ ' in the preterit of the indicated verbs.

The students in the honors class, group A, were a very motivated group. Everyone wanted to participate and share their mistakes with the rest of the class. For them it was not embarrassing to expose their mistakes because they understood its purpose, and they knew that when they found a solution to their mistakes, it would also serve to help other students who were having the same problems with those same grammar issues. Also in the class a ball (The class named the ball 'Gino'.) was thrown to individual students by the instructor and other students to promote spontaneous conversation and to minimize intimidation in front of the class. This created a very dynamic atmosphere in the classroom.

\section{Group b: ANOTHER UNIVERSITY STUDENT}

There is only one student in group B. Student B was close to graduating and was considered by his professors to be an excellent student. He is inventive, and he communicated with his Spanish instructor in Spanish about various strategies for learning. Regarding the differences between the verbs ser and estar (Both verbs mean 'to be' in English; the verb ser 
is used to describe essential characteristics of people and things; the verb estar is used to describe states or conditions of people and things.), he made the following comment: "Madonna is one of my favorite singers.... She changes all the time, so she is perfect to explain estar. Madonna the 'star' (estar) is singing. With estar everything changes. Now Madonna the estar is sick. Tomorrow she will be better. This helps me remember that estar is used for things that can change." Regarding por and para, this student, similar to student A3, also used the concept of a straight arrow for the preposition para and a curving arrow to illustrate por.

Another strategy that student B had for learning grammar was how to use direct and indirect objects: "You can never have the words $l e, l a$ and $l o$ together in one sentence. A way I remember this is by the title of a popular song called 'Lela'. It is about a man fighting to get a woman he can't have." The student continued: "In a sense, many people learning Spanish struggle because it sounds like $l e, l a$ and $l o$ should be together. This [song 'Lela'] helps me remember they should not [be together]," because the man cannot be together with the woman he can't have, Lela. This student was therefore able to instantly self-correct instead of simply being confused when the mistake was pointed out by someone else. It is also remarkable to see the motivation of this student to learn Spanish.

\section{GROUP C: HOME-SCHOOLED STUDENTS}

The following group of students, group C, was home-schooled. These students have been included in this study because of their unusually rapid learning of Spanish and their ability to attain relatively high levels of spoken and written Spanish in a short time as compared to so many students their own age and older. These students were given exams both written and oral. Their proficiency in Spanish was measured according to the ACTFL standards by certified teachers.

Student C1 started to learn Spanish and along with two other students (C2 and C3) had Spanish classes one time a week for an hour and a half. In only two years he reached the advanced level high on the ACTFL scale. This group was also taught some concepts of second language acquisition theory, and they were encouraged to teach others what they were learning. The level that the group $\mathrm{C}$ students reached is shown by what one of them wrote: "Currently I am the bilingual receptionist for a public health nurse working among the Hispanic population of Southern Chester County, Pennsylvania. I have earned credit for four years of high school Spanish and two years of college Spanish since I began studying the language two years ago." Another student in this group, C2 (15 years old), also reached an advanced level on the ACTFL scale. Her motivation was as great as that of student C1.

The $\mathrm{C}$ group students have a great interest in Spanish because of their desire to be involved in missionary work around the world. We can see the motivation in one group C student's own words: "Since I had a strong motivation to learn Spanish in order to help others, I did not mind working on my Spanish at night or at other of my 'free' time[s]." We are sure that this student will reach her goal, and she stated further: "This year ... I plan to take the CLEP standardized test in order to get four semesters of college credit for my few years of Spanish."

One of the group C students also invented ideas on how to learn Spanish vocabulary: "la cama 'bed'-get calm in your cama; la ropa 'clothes'-picture someone who is dressed up in a rope; la ventana 'window'-ventanas are 'vents'." 
Student C3 was also evaluated by the ACTFL proficiency scale and acquired an advanced level (equal to student C2). She also showed a very strong motivation to learn Spanish. She needed, however, more encouragement and reassurance that she was progressing well. In her own words: "If he [the instructor] sensed we were frustrated or confused, he would present the topic from a different angle, always searching for clues as to each of our particular learning styles and preferences." Many times it was necessary to adjust instruction (Krashen i+1). ${ }^{1}$ This student showed, however, a great auditory capacity due to her interest in music.

\section{GROUP D: HOME-SCHOOLED STUDENTS}

The following two home-schooled students (group D) are brothers and learned in ways similar to those of group C. Their motivation to learn Spanish was also very high due to their desire to do missionary work and live in and adapt to another culture. Student D1 was 17 years old; his brother, student D2, was 15 years old. Their instruction was in the target language, Spanish, and they both wrote a diary recording their progress and mistakes. The instructor provided clues to indicate their mistakes, but they had to find the correct forms themselves. Student D1 wrote: "The interesting thing was that the professor only marked what kind of mistake it was, but he didn't give me the solutions."

Students D1 and D2 made plans to go to Spain for an extended visit. Their progress was very fast. Before they left for Spain they were exposed to formal and informal conversation in Spanish as well as translation and simultaneous translation. Student D1 was evaluated twice after he returned from Spain, almost a year after having started this program of study. The result was a superior level on the ACTFL scale. Another professor certified in ACTFL said that his proficiency is now that of a native.

A learning strategy used by student D1 consisted of memory associations for various grammatical points, including the differences between the Spanish verbs ser and estar (both meaning 'to be' in English), similar to the strategy used by student B for the same verbs. Remember that the verb ser is used to describe essential characteristics of people and things; the verb estar is used to describe states or conditions of people and things. In the words of the student: "Instead of thinking of the verb ser, I thought of the English word sir, in particular 'Sir Charles', Prince of Wales. Then, I had to give a description of 'Sir Charles'Sir Charles es alto 'Sir Charles is tall', etc." Also in his own words he explained the association that he made with the Spanish verb estar: "This verb was a 'star' or a movie star, like Brad Pitt. To learn the concept of estar ... [one] has to give a description of the 'estar': the 'estar' Brad Pitt is in the movie, etc." (e.g. Brad Pitt está en la película. 'Brad Pitt is in the movie'; Brad Pitt está bien hoy. 'Brad Pitt is [feeling] fine today'.)

Student D1, along with the other students in all the groups, extended their own learning by tutoring or instructing other students who knew less Spanish than they did. Student D1 made use of learning situations found in Di Pietro (1987). For example, one D1's students

1 'Krashen i + 1' refers to Krashen's (Krashen, S. \& Terrell, T. 1983) input hypothesis of his second language acquisition theory in which $\mathrm{i}=$ comprehensible input plus one step more advanced than the language student's current capability, which serves to extend the student's acquisition one more step. 
wanted to be a pilot. D1 and his student imagine that they are on an airplane, and D1 is the pilot. They converse in Spanish. The pilot says, "Is everyone in their place?" The student says, "Yes." The pilot says, "Very well, but I don't know how to fly." Di Pietro recommends using learning situations that are meaningful to students. D1's student wanted to be a pilot, so D1 capitalized on that situation to make learning meaningful for him. D1's student was motivated to talk in Spanish to tell the pilot how to fly because he wanted to be a pilot himself.

Student D1 taught his brother (student D2) Spanish. Student D2 started studying Spanish in May and a little more than a month later went to Spain for two months. When he returned he was evaluated, and the results were an advanced level on the ACTFL scale, after only 3 months of study of and exposure to Spanish. Student D2 explained some of his strategies of learning grammar, for example the forming of $\mathrm{del}(\mathrm{de}+e l)$. He created an association of this grammatical feature with the children's song, "The farmer in the dell", and explained that by changing the name of "the farmer in the dell" to "the farmer OF the dell", an association is produced in the learner's mind concerning how to say 'of the' in Spanish (de 'of' $+e l$ 'the' $=$ del 'of the').

\section{Group E: HOME-SCHOOLED STUDENTS}

The following students (group E) were also home-schooled, but their instruction was by distance learning. The students conversed by telephone several times a month with their Spanish instructor, and they sent compositions to their instructor by e-mail.

Student E1 was a home-schooled student in North Carolina. This student was very motivated, and like the others, had a desire to live and work in Spanish-speaking countries. He received a native proficiency evaluation on the ACTFL scale. He described the mental images he used to help him learn, for example: With "preterit/imperfect, it helps me think of the preterit as a dot in the past, one action that I have completed. The imperfect, on the other hand, is more like a line. That is, it has no definite ending point, but was an action that I repeated or carried out for an indefinite length of time." Student E1, at age 17, had a great ability to take in language and practiced frequently. In his words: "I listen to different shortwave radio stations to get a feel for the language in different countries and to hear Spanish grammar that is a little more involved than what I can find on tapes."

Student E2 was a home-schooled student in Minnesota who was at an advanced level of Spanish after one year, according to the ACTFL scale. Referring to the problem of fossilization (errors becoming habits), student E2 expressed the need to make corrections and maintain correct forms: "I think it's very important to establish a solid foundation with the ABC's of a language before stepping into deeper water." She confessed that she based a lot of her learning of the imperfect on repetition: "I rely heavily on rote memorization. I ... think of the past imperfect form as the '-aba/-ía' form." Her memory strategies for the conditional tense included the following: "To remember this form I apply 'María's Law', which reminds me to keep the '-ar/-er/-ir' ending and add '-ía'." The conditional tense in Spanish adds '-ía' to the full infinitive, which ends in '-ar/-er/-ir'. She wrote of other memory strategies such as the following, in which she searches for similarities between Spanish and her native English: "I try to find the similarities, and I use them as much as I can. When there are no similarities, I try to come up with my own." She was very creative in this area. 
Student E3 is a mother in Alabama who wanted to learn Spanish in order to teach her own children Spanish at home. In one year of study she arrived at an ACTFL intermediate high level. Her motivation was very high because she wanted to communicate with Hispanics in her neighborhood and had already started to teach a Sunday school class in her church in Spanish.

\section{Group F: HOME-SCHOOLED STUDENTS}

The last group (group F) is a mother (F1) and her sons (F2 and F3) whom she also taught at home. Her main motivation was to teach her adopted son from Columbia the language and culture of his biological parents. This mother and her husband are translators for the deaf using American Sign Language; they are therefore acquainted with second language learning strategies.

The mother used a variety of learning methods. She wanted to make up her own phrases apart from memorizing the dialogs in the text book. She kept a diary in Spanish and learned from the corrections. According to one in group F, "When we read Spanish literature, we deconstructed words to figure why they were written in that form.... When we listened to the Destinos videos, ${ }^{2}$ we applied our knowledge of grammar (to understand whether something might happen or would happen, for example)." Group F followed up the study of grammar by communicating in Spanish.

Student F1 reached an advanced level on the ACTFL scale. Her sons, F2 and F3, went to Spain. Student F2 reached a native proficiency level in Spanish on the ACTFL scale and went on to study in Japan because he also wanted to be fluent in Japanese. Student F3 became fluent in Spanish which has also helped him to read and communicate in French. He also reads articles in German in his doctoral program in Mathematics at the University of California, Berkley.

\section{Conclusions}

The learning strategies used by each group of students can be summarized as follows: The students have constructed mental images that help them remember the correct uses of grammatical structure. Sometimes the images students invent seem silly or even absurd. Yet remembering these images has made language learning easier, more efficient, and very productive. Self motivation to learn Spanish also played a big role in boosting the learning achieved. This motivation was instrumental in initiating the creative mental images the students invented to aid their learning. We also see that students' frequent self analysis of errors is effective in the prevention of fossilization of performance errors which is a problem with students who are exposed exclusively or almost exclusively to purely communicative methods of instruction.

2 Destinos: An introduction to Spanish (Bill VanPatten) is a series of video episodes used to teach Spanish. It has been broadcast on television on PBS. 
Manuel Morales, Daniel J. Smith Spanish learning strategies of some good language learners

It is evident from the observations of this study that good language students use learning strategies that include mental and visual images and that these strategies together with the motivational factor form a powerful element for affective learning of the Spanish language and by implication of other second languages as well. It is thus probable that highly motivated students who use learning strategies that include mental images benefit most from learning a second language. Further qualitative and quantitative research will further define the details of learning strategies which include images and motivational factors. From the observations of this study, it already appears evident, however, that teachers of Spanish and other second languages should encourage these or similar learning strategies with their students.

\section{Bibliography}

Anderson, J. (1980). Cognitive psychology and its implication. New York: Freeman.

Di Pietro, R. J. (1987). Strategic interaction: Learning languages through scenarios. Cambridge: Cambridge University Press.

Krashen, S. and Terrell, T. (1983). The natural approach: Language acquisition in the classroom. Oxford: Pegamon.

O’Malley \& Chamot. (1990). Learning strategies in second language acquisition. Cambridge: Cambridge University Press.

Oxford, R. (1990). Language learning strategies: What every teacher should know. Boston: Heinle $\&$ Heinle Publishers.

VanPatten, B. (1992). Destinos: An introduction to Spanish (video series aired on PBS). WGBH Boston, Annenberg/CPB Project. 